\title{
PENGARUH STRATEGI PEMBELAJARAN BERBASIS KECERDASAN VISUAL SPASIAL TERHADAP HASIL BELAJAR SISWA PADA MATERI GERAK LURUS DI KELAS VII SMP NEGERI 2 STABAT
}

\author{
Ida Wahyuni dan Khairil Irfan Lubis \\ Jurusan Fisika, FMIPA Universitas Negeri Medan \\ Jl. Willem Iskandar, Psr V-Medan
}

\begin{abstract}
Abstrak. Berdasarkan hasil penelitian pretes diperoleh nilai rata-rata kelas eksperimen 42,71 dan nilai rata-rata kelas kontrol 42,28. Dari hasil uji beda nilai kedua kelas pada taraf signifikan $\alpha=0,05$ diperoleh $t_{\text {hitung }}=0,2024, t_{\text {tabel }}$ $=1,991$, maka dapat disimpulkan tidak terdapat perbedaan yang signifikan nilai pretes kedua kelas, artinya kedua kelas memiliki kemampuan awal yang sama. Selanjutnya dilakukan pembelajaran dengan strategi pembelajaran berbasis visual spasial pada kelas eksperimen dan pembelajaran konvensional pada kelas kontrol. Setelah pembelajaran diberikan pada kedua kelas dilakukan postes. Untuk kelas eksperimen diperoleh nilai rata-rata 74,42 dan untuk kelas kontrol 70,26. Hasil pengujian hipotesis dengan taraf signifikan 0,05 diperoleh $t_{\text {hitung }}=2,21$ dan $t_{\text {tabel }}=1,666$. Karena $t_{\text {hitung }}>t_{\text {tabel }}$ maka hipotesis alternatif diterima, sehingga dapat disimpulkan terdapat pengaruh strategi pembelajaran berbasis visual spasial terhadap hasil belajar siswa pada materi pokok Gerak Lurus di kelas VII semester I SMP Negeri 2 Stabat T.P 2012/2013.
\end{abstract}

Kata kunci: strategi pembelajaran, kecerdasan visual spasial, hasil belajar

\section{Pendahuluan}

Pendidikan adalah usaha sadar dan terencana untuk mewujudkan suasana belajar dan proses pembelajaran agar peserta didik secara aktif mengembangkan potensi dirinya untuk memiliki kekuatan spiritual keagamaan, pengendalian diri, kepribadian, kecerdasan, akhlak mulia, serta keterampilan yang diperlukan dirinya, masyarakat, bangsa, dan negara (UUD No 20 tahun 2003 Bab 1 Pasal 1 Ayat 1). Pembelajaran Fisika belum berkembang dengan baik. Kebanyakan siswa belajar Fisika dengan hafalan rumus tanpa memikirkan bagaimana cara membangun pemahaman mereka sendiri, sehingga sebagian besar konsep-konsep Fisika masih merupakan konsep yang abstrak. Interaksi dalam peristiwa belajar-mengajar tidak sekedar hubungan antara guru dengan siswa saja, tetapi berupa interaksi edukatif.
Fisika sebagai salah satu cabang dari IPA yang mempelajari gejala-gejala alam dan peristiwa alam baik yang dapat dilihat maupun yang bersifat abstrak. Dalam hal ini merupakan tantangan bagi guru yang berperan sebagai mediator dan fasilitator harus mampu merancang pembelajaran yang tepat agar siswa dapat memahami gejala-gejala alam dan peristiwa alam baik yang dapa dilihat ataupun yang bersifat abstrak. Namun, saat ini masih banyak didapati permasalahan dalam proses pembelajaran tersebut. Sebagaimana yang dialami peneliti ketika melakukan Program Pengalaman Lapangan Terpadu (PPLT). Berdasarkan pengamatan peneliti selama masa PPL tahun 2011, bahwa untuk pelajaran Fisika minat belajar siswa sangat kurang dan menganggap bahwa Fisika merupakan pelajaran yang sulit. Menurut pengamatan peneliti dalam membela- 
Wahyuni, I. dan Lubis, KI.: Pengaruh Strategi Pembelajaran Berbasis Kecerdasan Visual Spasial Terhadap Hasil Belajar Siswa Pada Materi Gerak Luruh di Kelas VII SMP Negeri 2 Stabat

jarkan Fisika, guru lebih sering menjelaskan dan menuliskan di papan tulis tanpa memVisualisasikan konsep-konsep Fisika yang masih abstrak bagi siswa. Sejalan dengan hal ini setelah peneliti melakukan observasi awal dengan menyebarkan angket kepada siswa kelas VII SMP Negeri 2 Stabat, diperoleh 53\% siswa berpendapat bahwa pelajaran Fisika merupakan pelajaran yang sulit. Sehingga siswa tidak termotivasi dan berminat untuk aktif ketika belajar Fisika. Tidak mengherankan jika nilai Fisika semester ganjil di kelas ini tergolong masih rendah. Bersumber dari Daftar Kumpulan Nilai (DKN) siswa kelas VII SMP Negeri 2 Stabat, diketahui nilai rata-rata Fisika untuk semester Ganjil tahun pelajaran 2011/ 2012 mencapai 66,1 sedangkan kriteria ketuntasan minimal (KKM) di sekolah tersebut adalah 65. Meskipun KKM sudah tercapai, namun nilai yang diperoleh siswa sudah ada nilai tambahan dari guru yaitu penilaian guru terhadap tugas pribadi/kelompok, kehadiran siswa, dan disiplin siswa. Fakta-fakta yang berkembang ini salah satunya disebabkan belum tepatnya strategi yang dikembangkan oleh guru dalam mengajarkan Fisika. Strategi yang dikembangkan masih lebih mengutamakan pencapaian materi dan penjelasan mengenai rumus-rumus Fisika. Strategi yang tepat dalam mengajarkan Fisika akan membantu siswa lebih memahami dan menikmati pelajaran ini.

Dalam hal ini, ditawarkan sebuah strategi pembelajaran yaitu strategi pembelajaran berbasis kecerdasan visual spasial. Strategi ini merupakan bagian dari strategi pembelajaran Multipple Intelegencies. Strategi pembelajaran kecerdasan visual spasial merupakan sebuah strategi pembelajaran yang akan peneliti terapkan berdasarkan teknik-teknik pengembangan kecerdasan visual spasial. Ada beberapa teknik yang bisa kita gunakan untuk mengembangkan kecerdasan visual spasial siswa seperti visualiasi, penggunaan warna, metafora gambar, sketsa gagasan, simbol grafis. Peneliti akan menerapkan strategi pembelajaran berbasis kecerdasan visual spasial pada materi pokok Gerak Lurus Beraturan karena pada materi ini masih banyak konsep-konsep Fisika yang bersifat abstrak. Melalui strategi kecerdasan visual spasial konsep-konsep Fisika yang masih abstrak pada materi pokok Gerak Lurus Beraturan akan divisualisasikan sehingga akan membantu siswa lebih memahami konsepkonsep Fisika pada materi pokok Gerak Lurus Beraturan.

Kecerdasan visual spasial, yang kadangkadang disebut kecerdasan visual atau visualspasial adalah kemampuan untuk membentuk dan menggunakan model mental (Gardner, 2003). Orang yang mmiliki kecerdasan ini cenderung berpikir dalam atau dengan gambar dan cenderung mudah belajar melalui sajiansajian vidio seperti film, gambar, vidio dan peragaan yang menggunakan model atau slide. Mereka gemar menggambar, melukis atau mengukir gagasan-gagasan yang ada dikepala dan sering menyajikan suasana serta perasaan hatinya melalui seni (Jasmine, 2007). Kecerdasan ini meliputi kepekaan pada warna, garis, bentuk, ruang dan hubungan antar unsur tersebut. Kecerdasan ini merupakan kemampuan untuk menayangkan, mempresentasikan ide secara visual spasial dan mengorientasikan diri secara tepat dalam matriks spasial (Amstrong, 2004). Kecerdasan visual-spasial meliputi kumpulan kemampuan yang saling berkait, termasuk perbedaan visual, pengenalan visual, proyeksi, gambaran mental, pertimbangan ruang, manipulasi gambar, dan duplikasi dari gambaran dalam atau eksternal, setiap atau semua yang dpat diekspresikan.

Stategi kecerdasan visual spasial telah lebih dahulu diteliti beberapa peneliti yang menyimpulkan bahwa melalui strategi pembelajaran ini, dapat meningkatkan hasil belajar Fisika dimana sebelum diterapkannya strategi berbasis kecerdasan visual spasial nilai rata-rata hasil belajar siswa 4,7 dan setelah diterapkan diperoleh rata-rata nilai hasil belajar 6,4. Meskipun pada penelitian tersebut terbukti dapat meningkatkan hasil belajar siswa, namun peneliti masih mempunyai kelemahan. Kelemahan-kelemahan sebelumnya akan menjadi pedoman peneliti berikutnya dengan memper- 
Wahyuni, I. dan Lubis, KI.: Pengaruh Strategi Pembelajaran Berbasis Kecerdasan Visual Spasial Terhadap Hasil Belajar Siswa Pada Materi Gerak Luruh di Kelas VII SMP Negeri 2 Stabat

baiki kelemahan-kelemahan tersebut. Kelemahannya adalah tidak menggunakan flowchart/ mind map sebagai media yang dapat membantu siswa untuk memaksimalkan kerja otak yang menuntut integrasi, keterkaitan, gambar, dan sifat acak dari suatu informasi serta visualisasi yang dilakukan peneliti sebelumnya hanya visualisai 2 dimensi. Solusinya peneliti akan menggunakan flowchart/mind dan juga melakukan visualisasi 3 dimensi sebagai media yang mendukung pembelajaran dan meningkatkan aktivitas dalam kerjasama yang baik antara siswa ketika belajar kelompok.

Berdasarkan uraian latar belakang di atas, penulis akan melaksanakan penelitian dengan tujuan untuk mengetahui hasil belajar siswa pada materi Gerak Lurus Berubah Beraturan dikelas VII SMP Negeri 2 Stabat Tahun Pembelajaran 2012/2013 selama pembelajaran dengan strategi kecerdasan visual spasial. Kemudian untuk mengetahui bagaimana minat siswa di dalam kelas saat saat melakukan pembelajaran Fisika pada materi gerak lurus, dan untuk mengetahui pengaruh strategi belajar visual spasial terhadap hasil belajar siswa.

\section{Metode Penelitian}

Penelitian ini dilaksanakan di SMP Negeri 2 Stabat. Penelitian ini dilaksanakan pada semester ganjil Tahun Pembelajaran 2012/ 2013. Populasi dalam penelitian ini adalah seluruh siswa kelas VII SMP Negeri 2 Stabat T.P 2012/2013 yang terdiri atas 7 kelas. Pengambilan sampel dilakukan secara cluster random sampling. Dari 7 kelas yang menjadi sampel penelitian ini adalah 2 kelas yaitu kelas VII-2 sebagai kelas eksperimen yang menerapkan strategi pembelajaran berbasis Kecerdasan Visual Spasial dan kelas VII-1 sebagai kelas kontrol yang menerapkan stretegi pembelajaran konvensional.

Penelitian ini dilaksanakan melalui langkah-langkah sebagai berikut:

\section{Tahap persiapan}

Kegiatan yang dilakukan dalam tahap ini meliputi persiapan-persiapan sehubungan dengan pelaksanaan penelitian.

\section{Jurnal Pendidikan Fisika \\ p-ISSN 2252-732X \\ e-ISSN 2301-7651}

2. Tahap pelaksanaan (melaksanakan pretes, melakukan analisis data pretes, melakukan pengajaran pada kedua kelas yaitu pada kelas eksperimen adalah pengajaran Fisika dengan menggunakan strategi pembelajaran berbasis kecerdasan visual spasial dan pada kelas kontrol adalah pengajaran Fisika dengan menggunakan model konvensional, melaksanakan Post-test, melakukan pengolahan data pre-test dan post-test, melakukan analisis data postes yaitu uji normalitas, uji homogenitas, uji t, pada kelas eksperiman dan kelas kontrol. Kemudian dilakukan uji hipotesis dan setelah uji hipotesis dapat diambil suatu kesimpulan).

Hipotesis yang diuji berbentuk:

$\mathrm{H}_{\mathrm{O}}: \quad \mu_{1}=\mu_{2}$ : Tidak ada pengaruh strategi pembelajaran berbasis visual spasial terhadap hasil belajar belajar siswa.

$\mathrm{H}_{1}: \mu_{1} \neq \mu_{2}$ : Ada pengaruh strategi pembelajaran berbasis visual spasial terhadap hasil belajar belajar siswa.

Uji yang digunakan adalah uji t seperti dibawah ini:

$$
t=\frac{\overline{X_{1}}-\overline{X_{2}}}{S \sqrt{\frac{1}{n_{1}}+\frac{1}{n_{2}}}}(\text { Sudjana, 2005) }
$$

\section{Hasil Penelitian dan Pembahasan Hasil Penelitian}

Setelah dilakukan penelitian diproleh data sebagai berikut:

Tabel 1. Data Pretes Kelas Eksperimen dan Kelas Kontrol

\begin{tabular}{|c|c|c|c|c|c|c|c|}
\hline \multicolumn{4}{|c|}{ Kelas Eksperimen } & \multicolumn{4}{|c|}{ Kelas Kontrol } \\
\hline Nilai & Frek. & $\begin{array}{c}\text { Rata- } \\
\text { rata }\end{array}$ & $\begin{array}{l}\text { Standar } \\
\text { Deviasi }\end{array}$ & Nilai & Frek. & $\begin{array}{c}\text { Rata- } \\
\text { rata }\end{array}$ & $\begin{array}{l}\text { Standar } \\
\text { Deviasi }\end{array}$ \\
\hline 30 & 5 & \multirow{8}{*}{42,71} & \multirow{8}{*}{9,02} & 30 & 5 & \multirow{8}{*}{42,28} & \multirow{8}{*}{8,77} \\
\hline 35 & 7 & & & 35 & 7 & & \\
\hline 40 & 6 & & & 40 & 7 & & \\
\hline 45 & 6 & & & 45 & 6 & & \\
\hline 50 & 5 & & & 50 & 5 & & \\
\hline 55 & 4 & & & 55 & 3 & & \\
\hline 60 & 2 & & & 60 & 2 & & \\
\hline & $=35$ & & & & $=35$ & & \\
\hline
\end{tabular}


Wahyuni, I. dan Lubis, KI.: Pengaruh Strategi Pembelajaran Berbasis Kecerdasan Visual Spasial Terhadap Hasil Belajar Siswa Pada Materi Gerak Luruh di Kelas VII SMP Negeri 2 Stabat

Tabel 2. Data Postes Kelas Eksperimen dan Kelas Kontrol

\begin{tabular}{|c|c|c|c|c|c|c|c|}
\hline \multicolumn{4}{|c|}{ Kelas Eksperimen } & \multicolumn{4}{|c|}{ Kelas Kontrol } \\
\hline Nilai & Frek. & $\begin{array}{l}\text { Rata- } \\
\text { rata }\end{array}$ & SD & Nilai & Frek & $\begin{array}{l}\text { Rata- } \\
\text { rata }\end{array}$ & SD \\
\hline 55 & 1 & \multirow{8}{*}{74,42} & \multirow{8}{*}{7,25} & 50 & 1 & \multirow{8}{*}{70,26} & \multirow{8}{*}{8,48} \\
\hline 60 & 1 & & & 55 & 2 & & \\
\hline 65 & 5 & & & 60 & 3 & & \\
\hline 70 & 4 & & & 65 & 8 & & \\
\hline 75 & 10 & & & 70 & 4 & & \\
\hline 80 & 11 & & & 75 & 8 & & \\
\hline 85 & 3 & & & 80 & 9 & & \\
\hline$\sum$ & $=35$ & & & $\sum$ & $=35$ & & \\
\hline
\end{tabular}

Tabel 3. Ringkasan Hasil Perhitungan Nilai Rata-Rata, Standar Deviasi, Dan Varians

\begin{tabular}{|l|c|c|c|c|}
\hline \multirow{2}{*}{ Hasil } & \multicolumn{2}{|c|}{ Kelas Eksperimen } & \multicolumn{2}{c|}{ Kelas Kontrol } \\
\cline { 2 - 5 } & $\begin{array}{c}\text { Nilai } \\
\text { Pretes }\end{array}$ & $\begin{array}{c}\text { Nilai } \\
\text { Postes }\end{array}$ & $\begin{array}{c}\text { Nilai } \\
\text { Pretes }\end{array}$ & $\begin{array}{c}\text { Nilai } \\
\text { Postes }\end{array}$ \\
\hline Rata-Rata & 42,71 & 74,42 & 42,28 & 70,26 \\
\hline Standar Deviasi & 9,02 & 7,25 & 8,77 & 8,48 \\
\hline Varians & 81,38 & 52,56 & 76,91 & 71,91 \\
\hline
\end{tabular}

Setelah data memenuhi persyaratan homogenitas dan normalitas maka dilakukan pengujian hipotesis. Dalam penelitian ini menggunakan uji beda (uji t). Dari hasil pemberian pretes kepada kelas eksperimen diperoleh nilai rata-rata 42,71 dan hasil pemberian pretes kepada kelas kontrol diperoleh nilai rata-rata 42,28. Kemudian setelah diberikan perlakuan, yaitu strategi pembelajaran berbasis kecerdasan visual spasial pada kelas eksperimen dan model pembelajaran konvensional pada kelas kontrol, diperoleh hasil postes pada kelas eksperimen dengan nilai rata-rata 74,42 dan hasil postes pada kelas kontrol dengan nilai rata-rata 70,26. Ringkasan perhitungan uji hipotesis kelas eksperimen dan kelas kontrol sebagai berikut:

Tabel 4. Ringkasan Perhitungan Uji Hipotesis

\begin{tabular}{|c|c|c|c|c|}
\hline Data Kelas & $\begin{array}{c}\text { Nilai } \\
\text { Rata } \\
\text { - rata }\end{array}$ & $\mathrm{t}_{\text {hitung }}$ & $\mathrm{t}_{\text {tabel }}$ & Kesimpulan \\
\hline Pretes Eksperimen & 42,71 & \multirow{2}{*}{0,20} & \multirow{2}{*}{1,90} & \multirow{2}{*}{ Terima $\mathrm{H}_{0}$} \\
\hline Pretes Kontrol & 42,28 & & & \\
\hline Postes Eksperimen & 74,42 & \multirow{2}{*}{2,21} & \multirow{2}{*}{1,90} & \multirow{2}{*}{ Terima $\mathrm{H}_{\mathrm{a}}$} \\
\hline Postes Kontrol & 70,26 & & & \\
\hline
\end{tabular}

Berdasarkan Tabel 4 di atas, hasil perhitungan uji perbedaan nilai rata-rata pretes kelas eksperimen dan kelas kontrol untuk $\alpha=0,05$ diperoleh $t_{\text {hitung }}=0,20$ dan $\mathrm{t}_{\text {tabel }}=1,90$, maka $-t_{\text {tab }}<t_{\text {hit }}<t_{\text {tab }}$ atau $-1,90<0,20<1,90$, berarti $\mathrm{H}_{\mathrm{o}}$ diterima, sehingga dapat disimpulkan bahwa kemampuan awal siswa pada kelas eksperimen sama dengan kemampuan awal siswa pada kelas kontrol sebelum diberikan perlakuan.

\section{Pembahasan}

Hasil penelitian menunjukkan bahwa ada perbedaan akibat pengaruh strategi pembelajaran berbasis visual spasial terhadap hasil belajar siswa pada materi Gerak Lurus kelas VII SMP Negeri 2 Stabat bila dibandingkan dengan menggunakan model pembelajaran konvensional. Hal ini dapat dilihat melalui data hasil penelitian yang diperoleh, dimana nilai rata-rata postest pada kelas eksperimen adalah 74,42 sedangkan nilai rata-rata postest pada kelas kontrol adalah 70,26. Dalam hal ini terdapat perbedaan nilai rata-rata postest kelas eksperimen dengan kelas kontrol sebesar 4,16.

Adanya peningkatan hasil belajar siswa dikelas eksperimen dikarenakan pada saat proses belajar mengajar dengan menggunakan strategi pembelajaran berbasis visual spasial didasarkan banyak hal yaitu strategi pembelajaran berbasis visual spasial ini menekankan kepada proses keterlibatan siswa secara penuh untuk dapat menemukan materi yang dipelajari dan menghubungkannya dengan Visualisasi kehidupan nyata sehingga mendorong siswa untuk dapat menerapkannya dalam kehidupan sehari-hari, dalam proses pembelajaran inquiry siswa tidak hanya berperan sebagai penerima pelajaran melalui penjelasan guru secara verbal, tetapi siswa berperan memvisualisasikan pelajaran. Keterampilan siswa dalam pembelajaran dengan menggunakan strategi pembelajaran berbasis visual spasial merupakan suatu proses yang bermula dari membayangkan sesuatu hal, merealistiskan hasil ilustrasi bayangan, dan membuat kesimpulan.

Strategi pembelajaran berbasis visual spasial membuat siswa lebih aktif dalam belajar, karena dengan model ini pengetahuan dan keterampilan yang diperoleh oleh siswa 
Wahyuni, I. dan Lubis, KI.: Pengaruh Strategi Pembelajaran Berbasis Kecerdasan Visual Spasial Terhadap Hasil Belajar Siswa Pada Materi Gerak Luruh di Kelas VII SMP Negeri 2 Stabat

diharapkan bukan hasil mengingat seperangkat fakta-fakta, tetapi hasil dari menemukan sendiri. Dengan model ini juga siswa dapat bekerja sama yaitu pada fase ketiga pelaksanaan eksperimen dan memberikan masukan-masukan pada siswa yang lain sehingga siswa yang kurang mampu menjadi lebih termotivasi untuk mempelajari materi. Tingkat pemahaman yang diperoleh siswa lebih mendalam karena siswa terlibat langsung dalam proses menemukan jawaban terhadap persoalan yang ada dan langsung mempraktekkannya sehingga proses pembelajaran lebih efektif dan efesien serta siswa lebih termotivasi untuk berpikir kreatif. strategi pembelajaran berbasis visual spasial ini sangat baik untuk siswa yang memiliki kemampuan memvisualisasilan dan juga membayangkan karena dengan model ini siswa menjadi lebih aktif dan terarah langsung pada intisari pembelajaran.

Awal dari tahap ini peneliti memberikan penjelasan kepada siswa tujuan yang harus dicapai baik tujuan yang berhubungan dengan penguasaan materi pelajaran yang harus dicapai, maupun tujuan yang berhubungan dengan proses pembelajaran serta memotivasi siswa agar lebih aktif dalam belajar. Akan sulit bagi siswa untuk melaksanakan suatu tugas dengan baik apabila belum mengetahui jelas tentang apa dan mengapa melakukan suatu kegiatan atau apabila kriteria keberhasilan belum diberitahukan secara terbuka. Pada saat menyajikan materi, peneliti memberikan visualisasi materi pelajaran kemudian siswa tertarik untuk segara mencari ilmu pasti dari Visualisasi tersebut untuk mengetahui kemampuan dasar dan siswa mengajukan beberapa pertanyaan untuk pengumpulan data dan hanya bisa dijawab peneliti, kemudian peneliti mengarahkan siswa untuk melakukan eksperimen dengan membagi siswa dalam kelompok, masing-masing kelompok terdiri dari 7 orang dan berjumlah 5 kelompok. Kemudian peneliti membagikan LKS ke masing-masing kelompok, dan siswa kelihatan sangat antusias dan semangat karena menurut siswa pembelajaran Fisika khususnya, akan sangat menarik jika ada percobaan. Peneliti terlebih dahulu menjelaskan percobaan sebelum siswa melakukan kegiatan tersebut agar siswa lebih paham dalam mengerjakan LKS dan juga mengawasi siswa, kemudian siswa mengolah menyimpulkan hasil dari percobaan kemudian mempresentasikannya, di sinilah siswa dituntut untuk dapat bekerja sama dan memberikan masukan-masukan pada siswa yang lain sehingga siswa yang kurang mampu menjadi lebih termotivasi untuk mempelajari materi yang kurang dimengerti.

Namun demikian, dalam pelaksanaannya selain aspek positif yang ditawarkan, juga ditemukan beberapa kendala nyata yang tidak bisa diabaikan ketika menerapkan strategi pembelajaran berbasis visual spasial masih terdapat harapan yang masih kurang terpenuhi, khususnya ketika kerja kelompok berlangsung masih terdapat siswa yang kurang aktif. Model ini akan lebih baik apabila siswa terlibat aktif selama proses belajar melalui kerja kelompok, maka sebaiknya untuk mencapai hasil yang maksimal maka sebaiknya jumlah siswa di dalam kelompok dikurangi. Dengan jumlah ini maka akan memungkinkan setiap siswa dalam kelompok dapat bekerja sama dengan aktif. Sementara jumlah siswa yang terlalu banyak dalam kelompok diskusi menyebabkan adanya siswa yang tidak aktif dalam pembelajaran dan hal ini akan mengganggu proses belajar dalam kelompok diskusi.

Hasil belajar yang diperoleh dalam penelitian ini hanya menggunakan alat ukur berupa tes tertulis dalam bentuk pilihan berganda. Harapan yang terkandung dalam model ini belum semuanya tercapai dengan hasil yang sangat baik, adapun faktor yang menyebabkan kondisi ini terjadi adalah disebabkan karena siswa kurang terbiasa dengan strategi pembelajaran berbasis visual spasial sebelumnya, sehingga butuh waktu penyesuaian dengan siswa saat proses pembelajaran berlangsung. Oleh sebab itu hendaknya dalam proses pembelajaran sebaiknya siswa diajarkan dengan meggunakan model pembelajaran yang lebih variatif supaya siswa mampu memahami materi pelajaran Fisika secara efektif dan efesien. 
Wahyuni, I. dan Lubis, KI.: Pengaruh Strategi Pembelajaran Berbasis Kecerdasan Visual Spasial Terhadap Hasil Belajar Siswa Pada Materi Gerak Luruh di Kelas VII SMP Negeri 2 Stabat

\section{Simpulan}

Hasil analisis yang dilakukan dalam penelitian ini diperoleh kesimpulan sebagai berikut:

1. Hasil belajar siswa setelah proses pembelajaran dengan menggunakan pembelajaran konvensional pada materi pokok Gerak Lurus di Kelas VII Semester II SMP Negeri 2 Stabat T.P 2012/2013 secara keseluruhan kurang baik.

2. Hasil belajar siswa setelah proses pembelajaran dengan strategi pembelajaran berbasis kecerdasan visual spasial pada materi pokok Gerak Lurus di Kelas VII Semester II SMP Negeri 2 Stabat T.P 2012/2013 secara keseluruhan baik.

3. Minat siswa saat melaksanakan pembelajaran Fisika masih kurang

4. Terdapat perbedaan pengaruh strategi pembelajaran berbasis kecerdasan visual spasial dengan model pembelajaran konven- sional terhadap hasil belajar siswa pada materi gerak Lurus di Kelas VII Semester II SMP Negeri 2 Stabat T.P 2012/2013. Hal ini dilihat dari rata-rata hasil belajar siswa pada kelas eksperimen yang menggunakan strategi pembelajaran berbasis kecerdasan visual spasial adalah 74,42 . Sedangkan ratarata hasil belajar siswa pada kelas kontrol yang menggunakan model pembelajaran konvensional adalah 70,26.

\section{Daftar Pustaka}

Amstrong, T. 2004. 7 Kinds Of Smart. Jakarta: Penerbit PT. Gramedia Pusataka Utama.

Gardner. 2003. (http://www.lamanpusatbahasa. com).

Jasmine, J. 2007. Panduan Praktis Mengajar Berbasis Multiple Intelligence. Bandung: Penerbit Nuansa.

Sudjana. 2005. Metoda Statistika. Bandung: Penerbit Tarsito. 